\title{
Effects of Short Term Practice of Anuloma Viloma Pranayama on Metabolic Fitness (METF) and Bone Integrity (BI)
}

\author{
Baljinder Singh BAL \\ Department of Physical Education (T), Guru Nanak Dev University, Amritsar, INDIA \\ Email: bal.glopehss@gmail.com
}

\begin{abstract}
To measure the therapeutic effects of Anuloma Viloma Pranayama on Metabolic Fitness (MetF) and Bone Integrity. Fifty, university level girls between the age group of 19-25 years were selected. The subjects were purposively assigned into two groups: Group-A: Experimental $\left(\mathrm{n}_{1}=25\right)$; Group-B: Control $\left(\mathrm{n}_{2}=25\right)$. The subjects from Group-A: Experimental were subjected to a 4-weeks Anuloma Viloma Pranayama. Student $t$ test for paired samples was utilized to compare the means of the pre-test and the post-test. Based on the analysis of the results obtained, we conclude that the significant differences were found in Metabolic Fitness (MetF) (i.e., Maximal Oxygen Consumption $\left(\mathrm{V}_{\mathrm{O} 2} \mathrm{max}\right)$ and blood pressure of University Level Girls. Insignificant between-group differences were noted in Blood Lipid, Blood Sugar and Bone Integrity of University Level Girls.
\end{abstract}

Keywords: anuloma viloma pranayama, metabolic fitness (MetF), bone integrity 


\section{Introduction}

Pranayama is an art of controlling the life force of breath It is an ancient yoga technique, a spiritual and physical practice which integrates the mind and body. Pranayama is a type of yogic practice which produces many systemic psycho-physical effects in the body, besides its specific effects on the respiratory functions. So, it has become a standard fare at health clubs and community recreation programmes Mishra (1997). Yoga aims through its practices to liberate a human being form the conflicts of duality (body-mind) and from the influences of the Gunas-the qualities of universal energy that are present in every human being (James, 2002). It is now almost a proved fact based on various investigations that a prolonged continuous yogic practice and anulom vilom pranayam, relieve respiratory ailments like Bronchial Asthma, chronic Bronchitis, Bronchiectasis, and Ventilatory functions are much improved in them (Yadav \& Das, 2001). Anulom Vilom Pranayam is one of the best and easy most breathing exercises for complete purification of body as well as mind. It completely cures most of the internal body diseases without any medicine. If practiced regularly with devotion, anulom vilom not only intensifies the inner strength of body but also enhances the divine powers (Chavhan, 2013). Breath is a dynamic bridge between the body and mind (Bjlani, 2004). With the help of Anulom-Vilom which is a controlled breathing one can achieve positive effects on body and mind. Its leads to the integration of the state of prana-the vital functionary mechanism of the body and ultimately restoring the state of health. Yoga writings use a variety of terms for this anulom vilom pranayam including nadi-shodhanam, nadi suddhi and Sukha purvaka (Sarvesh, 2004). Many researchers and Yogis have reported the benefits of practising pranayama on Diabetes Mellitus (8), Heart Rate and Nervous System (Jerath et al. 2006). Research through Yoga Meditation has also shown remarkable improvement in Patience, Physical Relaxation, Mental Stress relief (Joshi et al. 2008) and physical relaxation (Joshi et al. 2009) of the chosen subjects. There are various techniques of pranayama but we have applied the technique of Anuloma Viloma Pranayama on the subjects.

\section{Material and Methods}

Fifty, university level girls of Department of Physical Education (T), Guru Nanak Dev University, Amritsar between the age group of 19-25 years (Mean \pm SD: age 22.5 $\pm 2.072 \mathrm{yrs}$, height $5.318 \pm 1.240 \mathrm{ft}$, body mass $56.32 \pm 2.235 \mathrm{~kg}$ ) volunteered to participate in the study. The subjects were purposively assigned into two groups:

- Group-A: Experimental $\left(\mathrm{n}_{1}=25\right)$

- Group-B: Control $\left(\mathrm{n}_{2}=25\right)$

All the subjects were informed about the objective and protocol of the study. Distribution and demographics of subjects are brought forth in Table 1. 
Table 1. Distribution and Demographics of Subjects

\begin{tabular}{|l|c|c|c|}
\hline \multicolumn{5}{|c|}{$\begin{array}{c}\text { Sample Size } \\
(\mathbf{N = 5 0 )}\end{array}$} \\
\hline Variables & $\begin{array}{c}\text { Total } \\
(\mathbf{N}=\mathbf{5 0})\end{array}$ & $\begin{array}{c}\text { Experimental group } \\
\left(\mathbf{n}_{\mathbf{1}}=\mathbf{2 5}\right)\end{array}$ & $\begin{array}{c}\text { Control group } \\
\left(\mathbf{n}_{\mathbf{2}}=\mathbf{2 5}\right)\end{array}$ \\
\hline Age & $22.5 \pm 2.072$ & $22.2 \pm 2.217$ & $22.8 \pm 1.914$ \\
\hline Body Height & $5.318 \pm 1.240$ & $5.324 \pm 1.234$ & $5.312 \pm 1.268$ \\
\hline Body Mass & $56.32 \pm 2.235$ & $56.72 \pm 2.82$ & $55.92 \pm 2.158$ \\
\hline
\end{tabular}

This study is designed as a retrospective cross-sectional study. The subjects from Group-A: Experimental were subjected to a 4-weeks training of Anuloma Viloma Pranayama. This lasted 4 weeks and consisted of daily sessions.

- Maximal oxygen uptake (VO2max) was used as a measure of cardiopulmonary fitness and was assessed by a maximal running test on a treadmill. Maximal oxygen uptake was scaled relative to body weight $\left(\mathrm{mL} . \mathrm{min}^{-1 . \mathrm{kg}-2 / 3}\right)$.

- Blood samples $(10 \mathrm{ml})$ for the determination of lipid profiles were obtained. All of biochemical tests have been done with serum samples.

- Blood pressure was measured in supine posture by Sphygmomanometer. Two reading were taken 5 minutes apart and the mean of two was taken as the basal blood pressure.

- The blood sugar levels were measured by Digital Glucometer (ACCU-CHEK, Sr noGN20606850 manufactured by Roche Diagnostics India Pvt. Ltd, Mumbai).

- Bone mineral density (BMD) of lumbar spine (L2-L4) in anteroposterior view was measured by dual-energy X-ray absorptiometry (DXA) using a Hologic QDR 1500W (Bedford, MA, USA).

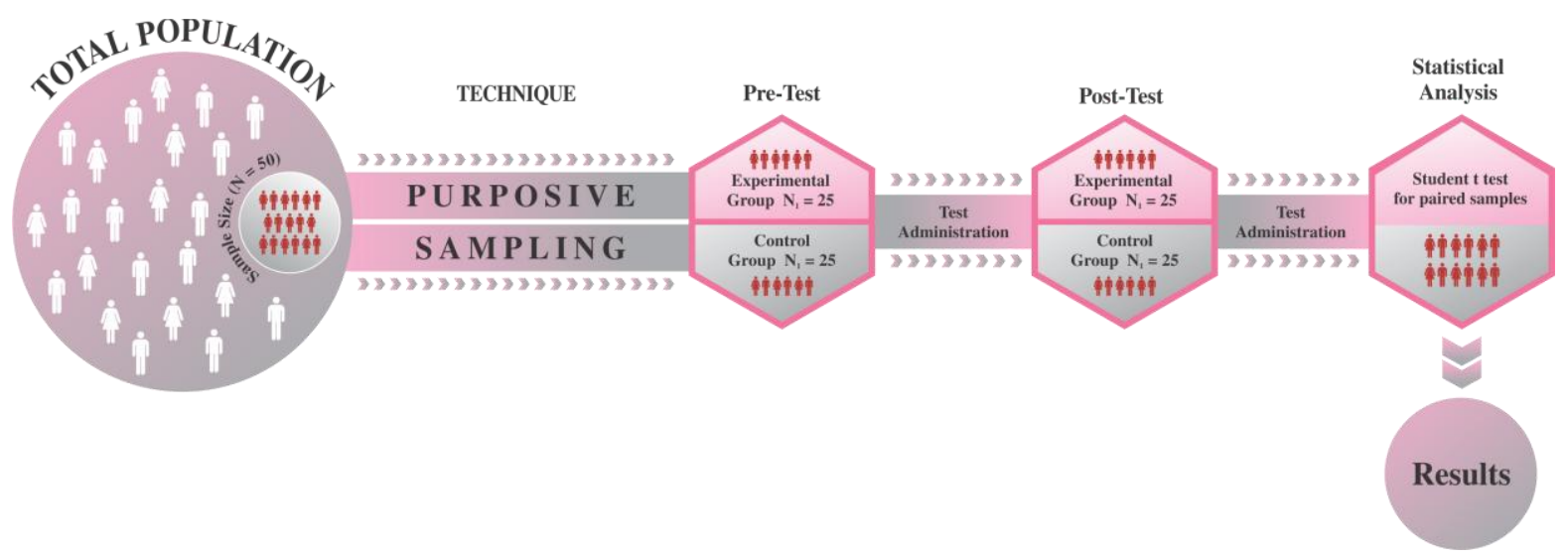

Figure 1. Study Design 
Table 2. Experimental Treatment

\begin{tabular}{|c|c|c|c|}
\hline \multicolumn{4}{|c|}{$\begin{array}{c}\text { 4-Weeks } \\
\text { Anuloma Viloma Pranayama Training } \\
\end{array}$} \\
\hline Weeks & Schedule & Time & Duration \\
\hline \multirow[t]{3}{*}{$\mathrm{I}^{\mathrm{st}}$ Week } & Preliminary Yogic Exercises & 5 Minute & \multirow{3}{*}{20 Minute } \\
\hline & $\begin{array}{c}\text { Practice of Anuloma Viloma Pranayama } \\
\text { (9 Rounds X 1 Set) }\end{array}$ & 10 Minute & \\
\hline & Relaxation Posture & 5 Minute & \\
\hline \multirow[t]{3}{*}{$2^{\text {nd }}$ Week } & Preliminary Yogic Exercises & 5 Minute & \multirow{3}{*}{25 Minute } \\
\hline & $\begin{array}{l}\text { Practice of Anuloma Viloma Pranayama } \\
\text { (9 Rounds X 2 Set) }\end{array}$ & 15 Minute & \\
\hline & Relaxation Posture & 5 Minute & \\
\hline \multirow[t]{3}{*}{$3^{\text {rd }}$ Week } & Preliminary Yogic Exercises & 5 Minute & \multirow{3}{*}{30 Minute } \\
\hline & $\begin{array}{l}\text { Practice of Anuloma Viloma Pranayama } \\
\text { (9 Rounds X } 3 \text { Set) }\end{array}$ & 20 Minute & \\
\hline & Relaxation Posture & 5 Minute & \\
\hline \multirow[t]{3}{*}{$4^{\text {rd }}$ Week } & Preliminary Yogic Exercises & 5 Minute & \multirow{3}{*}{35 Minute } \\
\hline & $\begin{array}{l}\text { Practice of Anuloma Viloma Pranayama } \\
\text { (9 Rounds X } 4 \text { Set) }\end{array}$ & 25 Minute & \\
\hline & Relaxation Posture & 5 Minute & \\
\hline
\end{tabular}
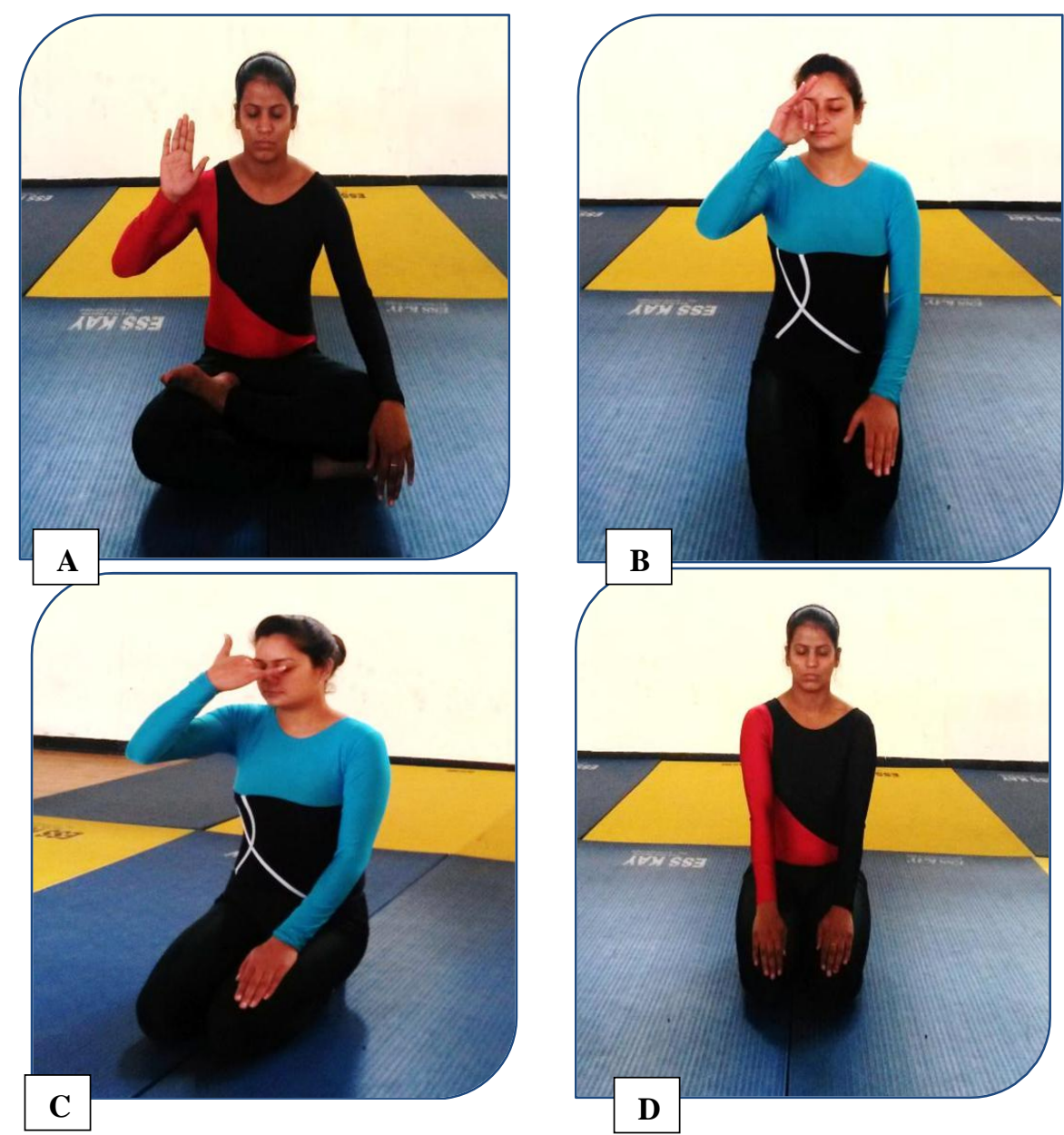

Figure 2. Subjects Performing Anuloma Viloma Pranayama 


\section{Statistical Analyses}

Data is expressed as the mean $\pm \mathrm{SD}$. Student $t$ test for paired samples was utilized to compare the means of the pre-test and the post-test.

\section{Results}

Table 3. Mean values $( \pm \mathrm{SD})$ and Paired Sample t-test of Metabolic Fitness (MetF) (i.e., Maximal Oxygen Consumption $\left(\mathrm{V}_{\mathrm{O} 2} \mathrm{max}\right)$, Blood Lipid and Blood Sugar) in Experimental and Control group ( $\mathrm{n}=25$ each) before (Pre) and after (Post) 4-weeks Anuloma Viloma Pranayama Training Programme (Experimental group only)

\begin{tabular}{|c|c|c|c|c|c|c|}
\hline \multicolumn{2}{|c|}{ Parameters } & Group & Pre-Test & Post-Test & t-value & $\begin{array}{l}\text { p- } \\
\text { value }\end{array}$ \\
\hline \multirow{2}{*}{\multicolumn{2}{|c|}{$\begin{array}{l}\text { Maximal Oxygen } \\
\text { Consumption }\left(\mathrm{V}_{\mathrm{O} 2} \max \right)\end{array}$}} & Experimen & $34.096 \pm 2.199$ & $34.908 \pm 1.489$ & $4.179 *$ & 0.0003 \\
\hline & & Control & $23.244 \pm 0.987$ & $23.096 \pm 0.969$ & 1.8212 & 0.0811 \\
\hline \multirow{4}{*}{$\begin{array}{l}\text { Blood } \\
\text { Lipid }\end{array}$} & \multirow{2}{*}{ Cholesterol } & Experime & $155.604 \pm 10.601$ & $159.652 \pm 10.455$ & 0.3674 & 0.7166 \\
\hline & & Control & $165.008 \pm 11.304$ & $165.004 \pm 11.271$ & 0.0665 & 0.9475 \\
\hline & \multirow[t]{2}{*}{ Triglycerides } & Exp & $147.040 \pm 1.344$ & $146.968 \pm 1.346$ & 1.0752 & 0.2930 \\
\hline & & Con & $135.908 \pm 8.985$ & $135.940 \pm 8.949$ & 1.3979 & 0.1749 \\
\hline \multirow{4}{*}{$\begin{array}{l}\text { Blood } \\
\text { Pressure }\end{array}$} & \multirow{2}{*}{$\begin{array}{l}\text { Systolic Blood } \\
\text { Pressure }\end{array}$} & Exp & $117.56 \pm 1.47$ & $118.68 \pm 1.14$ & $5.765^{*}$ & 0.0001 \\
\hline & & & & .27 & 0.3414 & 7358 \\
\hline & \multirow{2}{*}{$\begin{array}{l}\text { Diastolic Blood } \\
\text { Pressure }\end{array}$} & $\mathrm{Ex}_{1}$ & 5 & 83 & $5.5749 *$ & 0.0001 \\
\hline & & $\mathrm{Co}$ & 67 & 63 & 0.9121 & 0.3708 \\
\hline \multirow{4}{*}{$\begin{array}{l}\text { Blood } \\
\text { Sugar }\end{array}$} & \multirow{2}{*}{$\begin{array}{l}\text { Fasting Blood } \\
\text { Sugar }\end{array}$} & Experimental & $96.56 \pm 1.76$ & $97.16 \pm 2.12$ & 1.3887 & 0.1777 \\
\hline & & Control & $85.36 \pm 3.34$ & $85.80 \pm 3.19$ & 0.5415 & 0.5932 \\
\hline & \multirow{2}{*}{$\begin{array}{l}\text { Post Prandial } \\
\text { Blood Sugar }\end{array}$} & Experim & $127.44 \pm 1.12$ & $128.12 \pm 1.33$ & 1.9988 & 0.0571 \\
\hline & & Control & $133.64 \pm 4.50$ & $135.08 \pm 2.93$ & 1.2198 & 0.2344 \\
\hline
\end{tabular}

\section{Maximal Oxygen Consumption ( $\left.\mathrm{V}_{\mathrm{O} 2} \mathrm{max}\right)$}

The results of Metabolic Fitness (MetF) in group (Experimental) and group (Control) are shown in Table-3. The Mean and Standard Deviation $( \pm \mathrm{SD})$ values of Maximal Oxygen Consumption ( $\left.\mathrm{V}_{\mathrm{O} 2} \max \right)$ of pre-test and post-test of experimental group were $34.096 \pm 2.199$ \& $34.908 \pm 1.489$ respectively. However, the Mean and Standard Deviation $( \pm S D)$ values of Maximal Oxygen Consumption $\left(\mathrm{V}_{\mathrm{O} 2} \mathrm{max}\right)$ of pre-test and post-test of control group were $23.244 \pm 0.987 \& 23.096 \pm 0.969$. The $\mathrm{t}$-value in case of experimental group was $4.1794 *$ and for control group it was 1.8212 .

Significant between-group differences were noted in Maximal Oxygen Consumption $\left(\mathrm{V}_{\mathrm{O} 2} \mathrm{max}\right)$ in the experimental group before (Pre) and after (Post) subjected to 4-weeks Anuloma Viloma Pranayama Training Programme since, the calculated value of $(\mathrm{t}=4.1794 *)$ is greater than tabulated value of $t .05(24)=2.06$ for the selected degree of freedom and level of significance. However, no significant changes over that 4 -weeks period were noted in the control group.

\section{Cholesterol}

The Mean and Standard Deviation values $( \pm \mathrm{SD})$ of Cholesterol of pre-test and post-test of experimental group were $155.604 \pm 10.601$ and $159.652 \pm 10.455$ respectively. However, the Mean and Standard Deviation $( \pm \mathrm{SD})$ values of Cholesterol of pre-test and post-test of control 
group were $165.008 \pm 11.304$ and $165.004 \pm 11.271$. The $\mathrm{t}$-value in case of experimental group was 0.3674 and for control group it was 0.0665 .

Insignificant between-group differences were noted in Cholesterol in the experimental group before (Pre) and after (Post) subjected to 4-weeks Anuloma Viloma Pranayama Training Programme since, the calculated value of $(t=0.3674)$ is less than tabulated value of $t_{.05}(24)=$ 2.06 for the selected degree of freedom and level of significance. However, no significant changes over that 4- weeks period were noted in the control group.

\section{Triglycerides}

The Mean and Standard Deviation values $( \pm \mathrm{SD})$ of Triglycerides of pre-test and post-test of experimental group were $147.040 \pm 1.344$ and $146.968 \pm 1.346$ respectively. However, the Mean and Standard Deviation $( \pm \mathrm{SD})$ values of Triglycerides of pre-test and post-test of control group were $135.908 \pm 8.985$ and $135.940 \pm 8.949$. The t-value in case of experimental group was 1.0752 and for control group it was 1.3979.

Insignificant between-group differences were noted in Triglycerides in the experimental group before (Pre) and after (Post) subjected to 4-weeks Anuloma Viloma Pranayama Training Programme since, the calculated value of $(\mathrm{t}=1.0752)$ is less than tabulated value of $t_{.05}(24)=2.06$ for the selected degree of freedom and level of significance. However, no significant changes over that 4 -weeks period were noted in the control group.

\section{Systolic Blood Pressure}

The Mean and Standard Deviation $( \pm$ SD) values of Systolic Blood Pressure of pre-test and post-test of experimental group were $117.56 \pm 1.47 \& 118.68 \pm 1.14$ respectively. However, the Mean and Standard Deviation $( \pm \mathrm{SD})$ values of Systolic Blood Pressure of pre-test and posttest of control group were $126.20 \pm 3.20 \& 126.44 \pm 2.27$. The t-value in case of experimental group was $5.765^{*}$ and for control group it was 0.3414 .

Significant between-group differences were noted in Systolic Blood Pressure in the experimental group before (Pre) and after (Post) subjected to 4-weeks Anuloma Viloma Pranayama Training Programme since, the calculated value of $\left(\mathrm{t}=5.765^{*}\right)$ is greater than tabulated value of $t .05(24)=2.06$ for the selected degree of freedom and level of significance. However, no significant changes over that 4-weeks period were noted in the control group.

\section{Diastolic Blood Pressure}

The Mean and Standard Deviation $( \pm \mathrm{SD})$ values of Diastolic Blood Pressure of pre-test and post-test of experimental group were $76.28 \pm 2.05 \& 78.12 \pm 1.83$ respectively. However, the Mean and Standard Deviation $( \pm \mathrm{SD})$ values of Diastolic Blood Pressure of pre-test and posttest of control group were $83.76 \pm 2.67 \& 84.32 \pm 1.63$. The t-value in case of experimental group was 5.5749* and for control group it was 0.9121 .

Significant between-group differences were noted in Diastolic Blood Pressure in the experimental group before (Pre) and after (Post) subjected to 4-weeks Anuloma Viloma Pranayama Training Programme since, the calculated value of $\left(\mathrm{t}=5.5749^{*}\right)$ is greater than tabulated value of $t .05(24)=2.06$ for the selected degree of freedom and level of significance. However, no significant changes over that 4-weeks period were noted in the control group. 


\section{Fasting Blood Sugar}

The Mean and Standard Deviation $( \pm \mathrm{SD})$ values of Fasting Blood Sugar of pre-test and posttest of experimental group were $96.56 \pm 1.76 \& 97.16 \pm 2.12$ respectively. However, the Mean and Standard Deviation $( \pm \mathrm{SD})$ values of Fasting Blood Sugar of pre-test and post-test of control group were $85.36 \pm 3.34 \& 85.80 \pm 3.19$. The t-value in case of experimental group was 1.3887 and for control group it was 0.5415 .

Insignificant between-group differences were noted in Fasting Blood Sugar in the experimental group before (Pre) and after (Post) subjected to 4-weeks Anuloma Viloma Pranayama Training Programme since, the calculated value of $(t=1.3887)$ is less than tabulated value of $t_{.05}(24)=2.06$ for the selected degree of freedom and level of significance. However, no significant changes over that 4-weeks period were noted in the control group.

\section{Post Prandial Blood Sugar}

The Mean and Standard Deviation $( \pm \mathrm{SD})$ values of Post Prandial Blood Sugar of pre-test and post-test of experimental group were $127.44 \pm 1.12 \& 128.12 \pm 1.33$ respectively. However, the Mean and Standard Deviation $( \pm \mathrm{SD})$ values of Post Prandial Blood Sugar of pre-test and posttest of control group were $133.64 \pm 4.50 \& 135.08 \pm 2.93$. The t-value in case of experimental group was 1.9988 and for control group it was 1.2198 .

Insignificant between-group differences were noted in Post Prandial Blood Sugar in the experimental group before (Pre) and after (Post) subjected to 4-weeks Anuloma Viloma Pranayama Training Programme since, the calculated value of $(\mathrm{t}=1.9988)$ is less than tabulated value of $t_{.05}(24)=2.06$ for the selected degree of freedom and level of significance. However, no significant changes over that 4 -weeks period were noted in the control group.

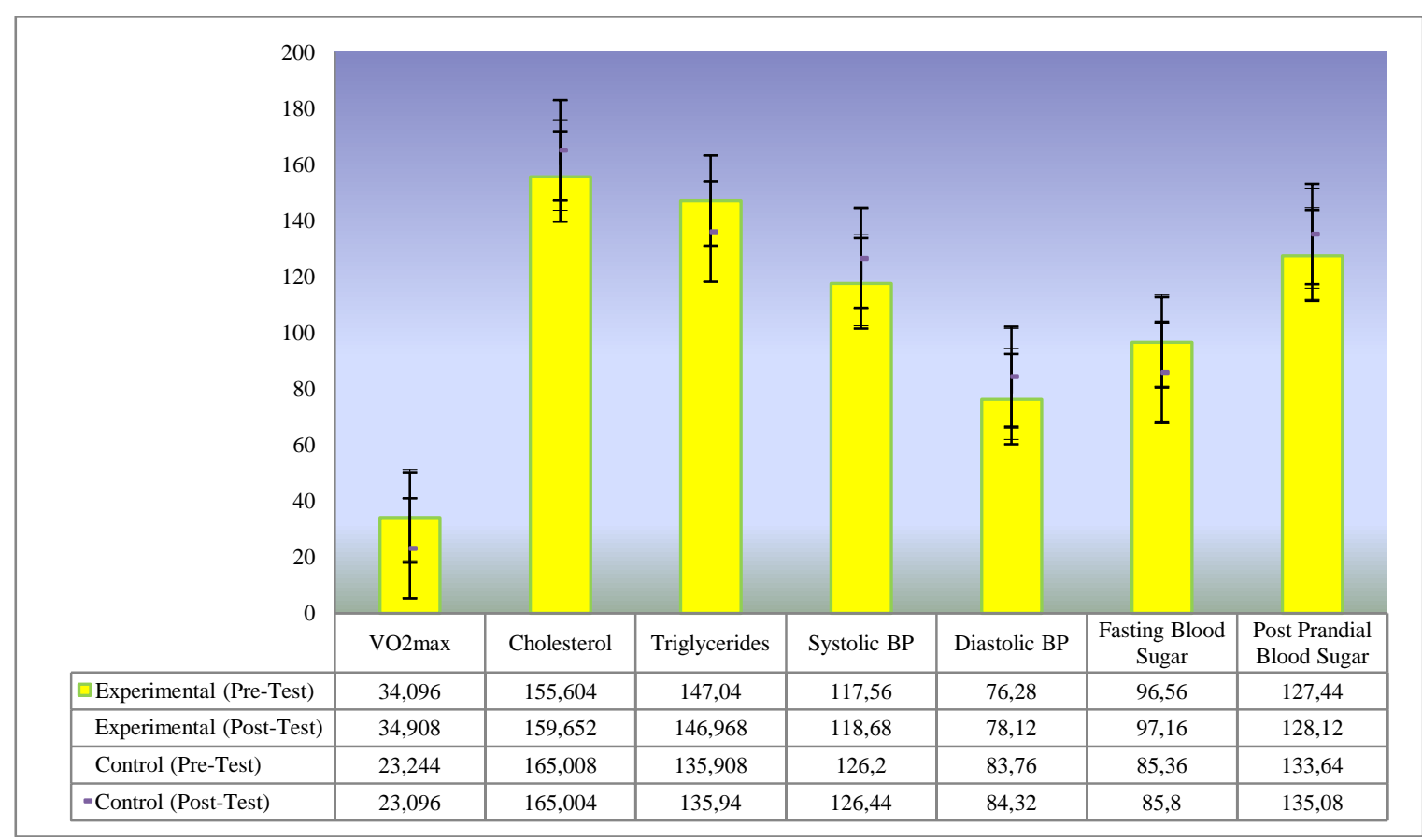

Figure 3. Mean values of Metabolic Fitness (MetF) (i.e., Maximal Oxygen Consumption ( $\left.\mathrm{V}_{\mathrm{O} 2} \mathrm{max}\right)$, Blood Lipid and Blood Sugar) in Experimental and Control group ( $\mathrm{n}=25$ each) before (Pre) and after (Post) 4-weeks Anuloma Viloma Pranayama Training Programme (Experimental group only) 
Table 4. Mean values $( \pm \mathrm{SD})$ and Paired Sample t-test of Bone Integrity in Experimental and Control group ( $\mathrm{n}=25 \mathrm{each}$ ) before (Pre) and after (Post) 4-weeks Anuloma Viloma Pranayama Training Programme (Experimental group only)

\begin{tabular}{|l|l|l|l|l|l|}
\hline Parameters & Group & Pre-Test & Post-Test & $\begin{array}{l}\text { t- } \\
\text { value }\end{array}$ & $\begin{array}{l}\text { p- } \\
\text { value }\end{array}$ \\
\hline Bone Integrity & Experimental & $1.1420 \pm 0.0158$ & $1.1380 \pm 0.0178$ & 1.2247 & 0.2326 \\
\cline { 2 - 6 } & Control & $1.1404 \pm 0.0239$ & $1.1372 \pm 0.0215$ & 0.8686 & 0.3937 \\
\hline
\end{tabular}

\section{Bone Integrity}

The Mean and Standard Deviation $( \pm \mathrm{SD})$ values of Bone Integrity of pre-test and post-test of experimental group were $1.1420 \pm 0.0158 \& 1.1380 \pm 0.0178$ respectively. However, the Mean and Standard Deviation $( \pm \mathrm{SD})$ values of Bone Integrity of pre-test and post-test of control group were $1.1404 \pm 0.0239 \& 1.1372 \pm 0.0215$. The $\mathrm{t}$-value in case of experimental group was 1.2247 and for control group it was 0.8686 .

Insignificant between-group differences were noted in Bone Integrity in the experimental group before (Pre) and after (Post) subjected to 4-weeks Anuloma Viloma Pranayama Training Programme since, the calculated value of $(\mathrm{t}=1.2247)$ is less than tabulated value of $t_{.05}(24)=2.06$ for the selected degree of freedom and level of significance. However, no significant changes over that 4 -weeks period were noted in the control group.

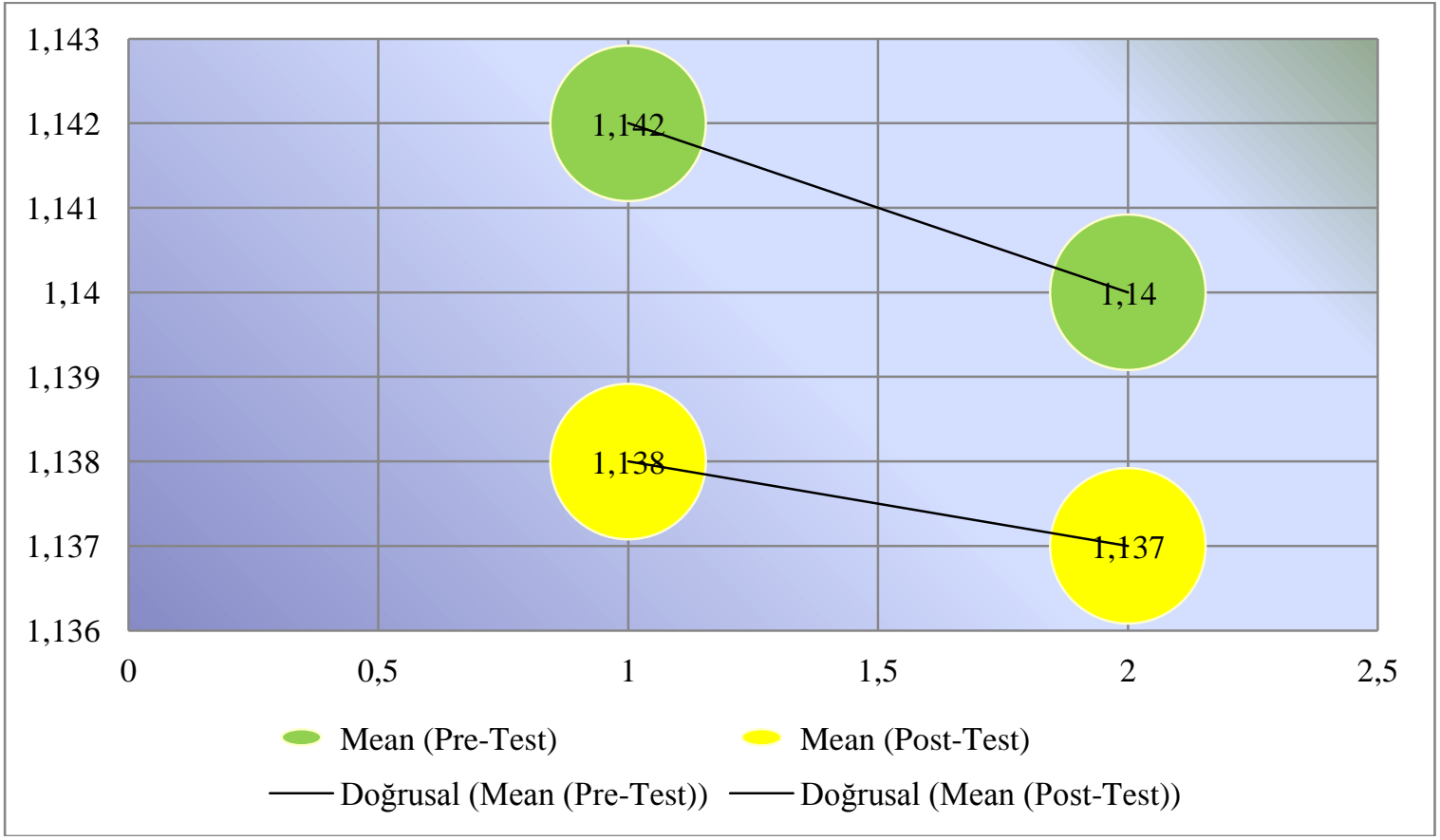

Figure 4. Mean values of Bone Integrity in Experimental and Control group ( $n=15$ each) before (Pre) and after (Post) 4-weeks Anuloma Viloma Pranayama Training Programme (Experimental group only) 


\section{Conclusion}

Based on the analysis of the results obtained, we conclude that the significant differences were found in Metabolic Fitness (MetF) (i.e., Maximal Oxygen Consumption $\left(\mathrm{V}_{\mathrm{O} 2} \mathrm{max}\right)$ and blood pressure of University Level Girls. Insignificant between-group differences were noted in Blood Lipid, Blood Sugar and Bone Integrity of University Level Girls.

\section{REFERENCES}

Bijilani RL (2004). The Yogic Practices: Asanas, Pranayamas and Kriyas. Understanding medical physiology, $3^{\text {rd }}$ edition, Jaypee Brothers Medical Publishers, New Delhi, India, 883889.

Chavhan DB (2013). The Effect of Anulom-Vilom and Kapalbhati Pranayama on Positive Attitude in School Going Children. Edubeam Multidisciplinary- Online Research Journal, VII, 1, 1-8.

James AR (2002). Psychophysiologic. Effects of Hatha yoga on musculoskeletal and cardiopulmonary function. A Literature Review. Journal of Alternative and complementary medicine, 8(6), 797-812.

Jerath R. Edry J, Barnes V, Jerath V (2006). Physiology of long pranayamic breathing: Neural respiratory elements may provide a mechanism that explains how slow deep breathing shifts the autonomic nervous system. Medical Hypotheses. 67(3), 566-571.

Joshi A, Singh M, Jindal R, Parkash J (2008). Role of Acoustic Meditation in Stress Management an Analysis. International Journal of Management Sciences. 4(2), 56- 67.

Joshi A, Joshi S, Singh M, Kaur S (2009). Stress A Bane - Yoga the Cure in National Seminar on Ayurveda. 20-24.

Mishra SP (1997). Yoga and Ayurveda: Their alliedness and scope as positive health sciences. 2nd ed. Varanasi, Chaukhambha Sanskrit Sansthan.

Sarvesh KA (2004). Pranayam- The Modulator of life, Chaukhamba Orientalia, First Edition, Chapter-5, 42.

Yadav RK, Das S (2001). Effect of yogic practice on pulmonary functions in young females. Indian Journal of Physiology and Pharmacology, 45(4), 493-496 